Wirawan Hardinto, Analisa Kritis Terhadap Praktek ...............

\title{
Analisa Kritis Terhadap Praktek Accounting Creative Dalam Perusahaan Yang Berbudaya Syariah (Studi Kasus Pada Layanan Kesehatan Yang Berbudaya Syariah)
}

\author{
Wirawan Hardinto*
}

\section{Abstract}

There are some factors that influence the corporation to do creative accounting. They are financial statement users who tend to see only on the net income at income statements, flexibility in Financial Accounting Standard and the cultural who have an influence to all elements in the organization. Accounting creative has variety interpretations, some interpret it positively, and the others negatively, in the positive interpretation, it's corporation activity who uses dccounting technic and policy to achieve a corporation's. result, or legal technic based on accounting rules or accounting standard. In the corporate culture contexs, creative accountings is an important management instruments which can be influenced by corporate culture.

Corporation has some motivations, while running the creative accounting, they are politic motivation, tax, bonus, loans and CEO replacement. This paper focuses on how the form of accounting creative's practice in the corporation which has cultural based on shariah. In the shariah cultural corporation, accounting creative's practice adopts a legal technic which based on accounting rules or accounting standard.

Keywords ; accounting creative, shariah cultural, accounting legal technic, accounting standard and accounting methods.

\section{Pendahuluan}

Pengguna laporan keuangan memiliki kecenderungan hanya memandang laba bersih dalam laporan laba rugi, hal ini memicu berkembangnya penggunaan teknik creative accounting. Creative accounting bukanlah pengetahuan baru, melainkan hanyalah kumpulan teknik dan kebijakan akuntansi yang telah ada, baik teknik akuntansi yang 
sederhana maupun yang komplek. Standar akuntansi yang memiliki fleksibiltas bisa dimanfaatkan oleh badan usaha untuk mengambil keuntungan atau manfaat, bergantung dari motivasi para manajer, apakah mereka oportunis atau tidak.

Sebuah badan usaha akan makin termotivasi untuk berperilaku kreatif dalam memanfaatkan teknik dan kebijakan akuntansi ketika badan usaha itu memiliki keyakinan (ekspektasi) akan menerima imbalan atas tindakan kreatifnya. Dengan kata lain semakin tinggi imbalan yang akan didapatkan, maka semakin tinggi juga ekspektasi yang ditetapkan sehingga motivasi untuk mencapai nilai tersebut makin besar.

Tapi manusia memiliki kecenderungan untuk mengutamakan diri sendiri, dan ketika terjadi konflik kepentingan, ikatan emosional, atau bias psikologis yang lain maka obyektivitas manusia dapat berkurang atau menghilang. Sehingga creative accounting bisa digunakan oleh para oportunis untuk mencapai kepentingan mereka. Pada prinsipnya creative accounting memiliki sifat seperti senjata api, di satu sisi bisa digunakan untuk membela diri tapi di sisi lain bisa digunakan untuk menyerang orang lain. Securities Exchange Commision (SEC) (1989) dalam Setiawan dkk (2011) menyampaikan bahwa fleksibilitas dalam akuntansi membuat prinsip akuntansi dapat disesuaikan dengan inovasi bisnis. Sayangnya untuk kepentingan diri sendiri, pihak-pihak yang terlibat dalam penyusunan laporan keuangan menyalahgunakan prinsip akuntansi ini dengan memanfaatkan celah atau area abu-abu antara legitimasi dan kecurangan.

Masalah yang terbesar dalam praktik akuntansi adalah masalah etika, filter yang paling baik dalam creative accounting adalah standar moral atau etika. Hendserson dan Peirson (2002) dalam Sulistiawandkk 
(2011) menjelaskan kriteria untuk menilai perilaku akuntan dalam pelaporan akuntan adalah sebagai berikut :

1. Kejujuran.

Kemampuan dan kemauan akuntan untuk menyampaikan realitas ekonomi yang terjadi dan tidak memberikan informasi yang menyimpang.

2. Reliabilitas.

Kemampuan untuk memberikan keyakinan bagi pihak pengguna laporan keuangan bahwa informasi tersebut dapat dipertanggungjawabkan.

3. Taat pada hukum.

Kebijakan dan teknik akuntansi harus sesuai aturan, pelanggaran terhadap aturan berarti melanggar hukum.

4. Kompetensi.

Kejujuran tanpa kompetensi juga merupakan pelanggaran etika, ketidakmampuan menganalisis fenomena bisnis menurut perspektif akuntansi mengakibatkan kesalahan dalam penyajian laporan keuangan.

Penggunaan creative accounting sebagai alat sangatlah bergantung dari para manajernya, bisa digunakan untuk tujuan yang baik dan sebaliknya, bisa digunakan untuk tujuan yang tidak baik. Jadi creative accounting memilik sifat seperti senjata api, bisa digunakan sebagai alat untuk melindungi tapi juga bịsa digunakan untuk membunuh orang. Menurut Watts dan Zimmereman, 1986, Horngren dan Foster (1991) dalam Triyuwono (2000) Akuntansi selama ini dipahami sebagai seperangkat 
prosedir rasional yang dijalin memenuhi kebutuhan informasi yang berguna bagi pengambil keputusan dan pengendalian yang rasional.

Pemahaman demikian menimbulkan tafsiran bahwa akuntansi adalah instrument yang terlepas dari lingkungan budaya maupun nilainilai dalam masyarakat. Dalam perkembangannya pemahaman tersebut mulai berbalik, menurut Eddy R. Rasyid (1998) dalam Widarto, dkk menyatakan bahwa budaya kerja perusahaan telah mempengaruhi praktek akuntansi khususnya praktek creative accounting perusahaan.

Budaya dalam organisasi berpengaruh dan mengarahkan pada personal-personal/anggota yang ada dalam organisasi tersebut, karena didalam budaya organisasi itu ada elemen-elemen berupa kepercayaan dan nilai-nilai/norma positif yang menjadi falsafah utama, hal ini melandasi dan menjadi pegangan bagi personal-personal organisasi. Menurut Nawawi (2003) dalam Widuridkk (2007) Budaya organisasi adalah suatu kepercayaan dan nilai yang menjadi falsafah utama yang dipegang teguh oleh anggota organisasi dalam menjalankan atau mengoperasionalkan kegiatan organisasi. Juga menurut Asrori Ardiansyah dalam Maryana (2010) Budaya organisasi pada dasarnya mewakili norma-norma perilaku yang diikuti oleh para anggota organisasi, termasuk mereka yang ada di dalam hierarki organisasi, sehingga budaya organisasi tersebut sangat penting perannya dalam mendukung terciptanya suatu organisasi yang efektif. Lebih spesifik lagi, budaya organisasi dapat berperan dalam menciptakan jati mengembangkan keikatan pribadi dengan organisasi sekaligus menyajikan pedoman perilaku kerja. 
Dari beberapa definisi budaya organisasi yang diungkapkan, budaya organisasi dapat disimpulkan sebagai norma-norma (falsafah utama, nilai-nilai positif) yang menjadi pegangan teguh dan mengarahkan perilaku para anggota di dalam organisasi dan budaya organisasi bisa menjadi instrument keunggulan kompetitif, berperan dalam penciptaan jati diri, mengembangkan keikatan pribadi dengan organisasi sekaligds menyajikan pedoman perilaku kerja dan berpengaruh pada semua aktivitas di dalam organisasi.

Akuntansi tidak terlepas dari organisasi yang menjadi lingkungannya, akuntansi juga memiliki fleksibilitas seiring dengan dinamika organisasi. Menurut Triyuwono (2000) dalam perkembangan akuntansi, akuntansi dipahami dalam konteks yang lebih luas, yaitu daiam konteks organisasi dan sosial, akuntansi dipandang sebagai sebuah entitas yang terus menerus berubah, tidak dipandang entitas yang statis dan sudah selesai, melainkan sebuah sebagai sesuatu yang mengalami perubahan terus menerus tergantung pada lingkungannya.

Akuntansi merupakan insrumen vital dalam organisasi, manajemen tidak bisa terlepas dari peranan akuntansi, menurut Triyuwono (2000)akuntansi dalam praktek nyata dalam organisasi perusahaan telah membantu manajemen dalam organisasi untuk melihat secara jelas fenomena abstrak dan konseptual yang tidak pernah mereka pikirkan sebelumnya, misalnya pemaknaan laba dan biaya dalam praktek akuntansi dewasa ini merupakan symbol-simbol umum dan secara lazim memang diterima. Menurut Soedjono (2005) dalam Maryana (2010) Budaya organisasi merupakan sistem informasi akuntansi yang meliputi 
penyebaran kepercayaan dan nilai-nilai yang berkembang dalam suatu organisasi dan mengarahkan perilaku anggota-anggotanya.

Budaya organisasi juga dapat menjadi instrumen keunggulan kompetitif yang utama, yaitu bila budaya organisasi mendukung strategi organisasi, dan bila budaya organisasi dapat menjawab atau mengatasi tantangan lingkungan dengan cepat dan tepat. Jadi praktek creative accounting mempunyai hubungan dan dipengaruhi oleh budaya organisasi perusahaan, karena pelaku creative accounting adalah personal-personal/ anggota dalam organisasi perusahaan, sedangkan mereka juga dipengaruhi dan diarahkan oleh nilai/norma-norma yang menjadi unsur budaya.

\section{Metodologi Penelitian}

Untuk mendukung penelitian ini, metodologi yang digunakan adalah metodologi etnografi, menurut Rudkin (2002) dalam Widarto dkk, metodologi etnografi dalam kajian akuntansi telah menempatkan peneliti dalam konteks situsnya, mengasah kepekaan mereka terhadap pemahaman budaya yang khas disana. Lokasi penelitian ditetapkan di sebuah perusahaan layanan kesehatan PT. ABC-RS XYZ yang beralamat di Daerah Istimewa Yogyakarta (DIY) Adapun teknik pengambilan data dilakukan dengan interaksi langsung, melibatkan diri dalam pekerjaan subjek dan wawancara dengan seluruh personal di Departemen Keuangan dan Akuntansi baik dengan para Manajer, Supervisor dan Staf.

Penulisan ini difokuskan pada kebijakan-kebijakan akuntansi, metode-metode akuntansi dan teknik akuntansi yang dianut perusahaan dalam penyajian laporan laba dan penilaian aset, umur ekonomis dan persentase kebijakan piutang tidak tertagihyang ditetapkan manajemen. 
Tinjauan Pustaka

Creative Accounting/Akuntansi Kreatif

Creative accounting didefinisikan secara beragam, ada yang mendefinisikan secara positif, secara negatif, secara. netral (tidak memihak), secara skeptis (cenderung tidak menyetujui) bahkan beberapa referensi menyebut sebagai magic accounting, cosmetic accounting dan financial shenigan. Istilah lain dari creative accounting adalah manajemen laba/earnings management, walaupun kedua istilah ini berbeda tapi merupakan aktivitas yang sama.

Dalam definisi yang positif, menurut Sulistiawandkk (2011), Creative accounting/akuntansi kreatif adalah aktivitas badan usaha memanfaatkan teknik dan kebijakan akuntansi guna mendapatkan hasil yang diinginkan. Teknik-teknik dalam creative accounting pun beragam, mulai teknik legal yang dibolehkan dalam SAK, sampai dengan teknk ilegal yang yang bertentangan dan tidak diperbolehkan dalam SAK.

Menurut Amat, Oriol dan Gwanthorpe (2004) dalam Sulistiawandkk, (2011), creative accounting merupakan transformasi informasi keungan dengan menggunakan pilihan metode, estimasi dan praktik akuntansi yang diperbolehkan oleh Standar Akuntansi. Myddelton (2009) dalam Sulistiawan dkk (2011) menyatakan bahwa akuntan yang dianggap kreatif adalah akuntan yang menginterprestasikan area abu-abu (grey area) untuk mendapatkan manfaat atau keuntungan dari hasil interprestasi tersebut. 


\section{Motivasi Creative Accounting}

Passer dan Smith (2008) dalam Sulistiawan (2011) mendefinisikan motivasi sebagai proses yang mempengaruhi arah, ketekunan dan kekuatan perilaku individu atau organisasi dalam mencapai tujuan. Dalam konteks creative accounting, sebuah badan usaha akan makin termotivasi untuk berperilaku kreatif dalam memanfaatkan teknik dan kebijakan akuntansi ketika badan itu memiliki keyakinan (ekspektasi) akan menerima imbalan atas tindakan kreatifnya tersebut. Manajemen laba sebagai salah satu bentuk tindakan creative accounting.

Secara umum terdapat beberapa hal yang memotivasi individu atau badan usaha melakukan manajemen laba, diantaranya adalah sebagai berikut :

1. Motivasi Bonus.

Dalam sebuah perjanjian bisnis, pemegang saham akan memberikan sejumlah insentif dan bonus sebagi feedback atas kinerja manajer dalam menjalankan operasional perusahaan. Kinerja manajemen salah satunya diukur dari pencapaian laba usaha. Pengukuran kinerja berdasarkan laba dan skema bonus tersebut memotivasi para manajer untuk memberikan performa terbaiknya sehingga tidak menutup peluang mereka melakukan tindakan creative accounting agar dapat menampilkan kinerja (performance) yang baik demi mendapatkan bonusn maksimal.

2. Motivasi Utang.

Untuk kepentingan ekspansi perusahaan, manajer sering kali menjalin kontrak bisnis dengan pihak ketiga, dalam hal ini adalah kreditor.

Agar kreditor mau menginvestasikan dananya ke dalam perusahaan, maka manajer harus menunjukkan performa baik mengenai 
perusahaannya, dan untuk memperoleh pinjaman dalam jumlah yang besar, perilaku kreatif manajer untuk menampilkan performa yang baik dari laporan keuangannya pun sering muncul.

3. Motivasi Pajak.

Tindakan creative accounting juga untuk kepentingan perpajakan. Untuk perusahaan yang belum go public cenderung melaporkan dan menginginkan untuk menyajikan laporan laba fiskal yang lebih rendah dari nilai sebenarnya.

4. Motivasi Penjualan Saham.

Motivasi ini banyak digunakan oleh perusahaan yang go public, proses penjualan saham perusahaan ke publik akan direspon positif oleh pasar ketika emiten mampu memperlihatkan kinerja yang baik. Salah satu ukuran kinerja yang dilihat oleh calon investor adalah penyajian laporan keuangan perusahaan. Kondisi ini sering memotivasi manajer untuk berperilaku kreatif dengan berusaha menampilkan kinerja keuangan yang lebih baik dari biasanya.

5. Motivasi Pergantian Direksi

Praktik manajemen laba biasanya terjadi pada sekitar periode penggantian direksi. Menjelang berakhirnya masa jabatan, direksi cenderung bertindak kreatif dengan memaksimalkan laba agar performa kerjanya tetap terlihat baik pada tahun terakhir jabatannya. Perilaku ini ditujukan dengan peningkatan laba agar performa kerjanya tetap terlihat baik pada tahun terakhir jabatannya. Motivasi utama yang mendorong perilaku kreatif tersebut adalah untuk memperoleh bonus yang maksimal pada akhir masa jabatannya. 
6. Motivasi Politik

Motivasi ini biasanya terjadi pada perusahaan besar yang bidang usahanya banyak menyentuh pada kepentingan masyarakat luas seperti perusahaan-perusahaan industri strategis seperti minyak, gas, listrik demi tetap mendapatkan subsidi, perusahaan cenderung menjaga posisi keuangannya dalam keadaan tertentu sehingga prestasi atau kinerjanya tidak terlalu baik. Pada aspek ini manajer cenderung melakukan kreativitas akuntansi untuk menyajikan laba yang lebih rendah dari nilai yang sebenarnya.

\section{Teknik Legal Dalam Creative Accounting}

Teknik legal yang biasanya dijumpai dalam creative accounting adalah :

1. Mengubah metode akuntansi.

Metode akuntansi merupakan pilihan-pilihan yang disediakan oleh Standar Akuntansi dalam menilai aset perusahaan. Beberapa bentuk pilihan metode akuntansi antara lain sebagai berikut :

a. Metode penilaian perusahaan (FIFO/LIFO, rata-rata tertimbang dan lain-lain).

b. Metode penyusutan aset tetap (garis lurus/saldo menurun, jumlah angka tahun, unit produksi).

c. Leasing (capital lease atau operating lease).

d. Investasi pada obligasi (trading securities).

e. Penggunaan harga pasar atau nilai buku pada aset jangka panjang.

f. Pembelian kembali saham perusahaan atau treasury stock (metode cost dan par). 
g. Pengakuan pendapatan (metode prosentase penyelesaian, saat penjualan dan pada saat-penerimaan kas).

2. Membuat estimasi akuntansi.

Teknik ini dilakukan dengan tujuan mempengaruhi laba akuntansi melalui kebijakan dalam membuat estimasi akuntansi, beberapa bentuk estimasi akuntansi antara lain sebagai berikut :

a. Estimasi dalam menentukan besarnya jumlah piutang tidak tertagih, baik dengan prosentase penjualan maupun prosentase piutang.

b. Estimasi dalam menentukan umur ekonomis aset, baik aset tétap maupun aset tidak berwujud

c. Estimasi tingkat bunga pasar yang digunakan untuk mendiskonto arus kas pada masa mendatang untuk penilaian kewajaran aset yang tidak memiliki pembanding atau kewajaran nilai obligasi.

3. Mengubah periode pengakuan pendapatan dan biaya.

Teknik ini dilakukan dengan cara mempercepat atau menunda pengakuan pendapatan dan biaya dengan cara menggeser pendapatan dan biaya ke periode berikutnya agar memperoleh laba maksimum.

4. Mereklasifikasi akun current dan non current.

Teknik ini dilakukan dengan cara memindahkan posisi akun dari satu tempat ke tempat lainnya.

Laporan keuangan sebenarnya disajikan sudah sama, tapi karena dilakukan reklasifikasi sehingga akan menimbulkan perbedaan interprestasi yang berbeda bagi penggunanya.

5. Mereklasifikasi akrual diskresioner dan akrual non diskresioner. 
Teknik ini dilakukan dengan cara menaikan atau menurunkan nilai akrual sehingga akan laba akan naik atau turun sesuai dengan kebijakan strategi manajemen.

Menurut Mohanram (2003) dalam Sulistiawan dkk (2011), untuk mendeteksi praktik manajemen laba, analisis akuntansi bisa dilakukan dengan beberapa tahapan sebagai berikut :

1. Mengidentifikasi kebijakan akuntansi utama yang digunakan oleh sebuah perusahaan atau industri.

2. Menilai penggunaan fleksibilitas akuntansi perusahaan, yaitu seberapa fleksibel perusahaan menerapkan kebijakan akuntansinya, contoh seberapa sering perusahaan melakukan perubahan estimasi dan kebijakan akuntansi, jika sering berarti bisa menjadi indikator bahwa perusahaan sedang melakukan "atraksi" akuntansi.

3. Menilai strategi yang digunakan perusahaan, yaitu sejauh mana perbedaan kebijakan akuntansi perusahaan lain.

4. Menilai kualitas pengungkapan perusahaan, yaitu dengan menilai apakah apakah perusahaan telah menyediakan informasi yang memadai untuk menilai strategi dan memahami kondisi ekonomi dari kegiatan operasinya.

5. Mengidentifikasi adanya potensi permasalahan akuntansi (potencial red flag), potensi permasalahan akuntansi dapat diidentifikasi dari hal-hal sebagai berikut :

a. Adanya perubahan akuntansi yang tidak dapat dijelaskan, khususnya ketika kinerja perusahaan sedang memburuk .

b. Adanya transaksi-transaksi yang melambungkan laba yang tidak dapat dijelaskan. 
c. Adanya peningkatan gap antara laba bersih dengan dan aliran kas perusahaan.

d. Adanya peningkatan gap antara laba bersih yang dilaporkan dan laba untuk tujuan pajak.

e. Adanya penghapusan (writedowns) aset dalam jumlah besar secara tiba-tiba atau tak terduga.

f. Adanya penyesuaian pada kuarter keempat yang luas. Bagi perusahaan yang berusaha memenuhi target laba tertentu, kuarter keempat adalah tempat berimprovisasi untuk mencapai target itu.

g. Adanya opini audit yang qualified atau adanya perubahan auditor.

h. Adanya transaksi-transaksi yang banyak berkaitan dengan pihak-pihak yang memiliki hubungan istimewa.

\section{Hasil dan Pembahasan}

Budaya Dalam Perusahaan

Menurut Griffin \& Ebbert (2002) bahwa perusahaan memiliki identitas yang unik, yang disebut sebagai budaya perusahaan (corporate culture), budaya perusahaan adalah pengalaman, kisah, kepercayaan dan norma-norma bersama yang memberikan ciri pada sebuah organisasi. Budaya berasal dari berdirinya awal berdirinya perusahaan. Demikian juga dengan perusahaan ini, sejak awal berdirinya, perusahaan ini sudah mendasarkan dirinya pada budaya atau nilai-nilai islam.

Ciri-ciri budaya yang islami ini bisa dilihat pada :

1. Visi, misi organisasi perusahaan yang dilandasi dan didominasi nilai-nilai/unsur keislaman. 
2. Aktivitas-aktivitas personal baik itu aktivitas rutin back office maupun aktivitas layanan kepada konsumen perusahaan.

3. Hubungan antar personal di internal perusahaan.

4. Dalam hal performa karyawan.

5. Seluruh personal perusahaan beragama islam.

\section{Teknik Akuntansi Legal Yang Dijalankan Perusahaan}

Menurut Sulistiawan dkk (2011), Metode akuntansi merupakan pilihan-pilihan yang disediakan oleh standar akuntansi (accounting choices) dalam menilai aset perusahaan, pilihan metode akuntansi tertentu akan memberikan outcome yang berbeda, baik bagi manajemen, pemilik maupun pemerintah.

Pemilihan metode akuntansi tertentu yang dilakukan oleh pengelola perusahaan merupakan salah satu bentuk maksimalisasi nilai perusahaan menurut perspektifnya masing-masing, sepanjang pemilihan tersebut sejalan dengan rambu-rambu yang sudah diatur dalam SAK. Pengangkatan Manajer Akuntansi dalam perusahaan mencerminkan perusahaan sangat concern terhadap akuntansi sangat tinggi. Manajer Akuntansi bertanggung jawab langsung kepada Direktur Keuangan, dalam struktur organisasi di Departemen Akuntansi, Manajer Akuntansi membawahi 3 Supervisor, Supervisor Akuntansi Umum, Supervisor IT (informasi dan Teknologi) dan Supervisor Cost Control, Manajer Akuntansi memiliki otonomi dalam pencatatan/pengakuan transaksitransaksi maupun sistem akuntansi, setiap tahun Departemen Akuntansi diaudit oleh Kantor Akuntan Publik Independen.

Teknik legal akuntansi yang dijalankan oleh perusahaan khususnya di Departemen Akuntansi di perusahaan ini adalah : 
1. Pemilihan Metode Penyusutan Garis Lurus (Straight Line Method)

Perusahaan secara konsisiten menerapkan metode penyusutan garis lurus (Straight Line Method) sebagai metode penyusutan aset tetap maupun aset tidak berwujud dari tahun berdirinya perusahaan 2007 sampai dengan 2012. Aset tetap dan asset tidak berwujud yang dimiliki perusahaan dikelompokkan ke dalam 8 kelompok besar yaitu ; IT, Peralatan Medis, Alat Transportasi, Perlengkapan Kamar Pasien, Perlengkapan Masak, Peralatan Masak, Peralatan Lain dan Aset Tidak Berwujud yaitu Beban Pra Operasi/Beban Tangguhan.

Menurut Catatan Atas Laporan KeuanganYang Berakhir Tanggal 31 Desember 2012 dan 2011 PT.ABC-RS.XYZ, Beban tangguhan adalah biaya-biaya yang terjadi sehubungan dengan biaya pra operasi dan diamortisasi dengan menggunakan metode garis lurus selama 10 tahun.

Tabel 1. Perbandingan Perhitungan Beban Depresiasi Antara Kebijakan Perusahaan (Metode Garis Lurus) dan Metode Saldo Menurun

\begin{tabular}{|c|c|c|}
\hline Tahun & $\begin{array}{c}\text { Beban depresiasi } \\
\text { Menurut kebijakan } \\
\text { perusahaan (metode garis } \\
\text { lurus) }\end{array}$ & $\begin{array}{c}\text { Beban depresiasi } \\
\text { (metode saldo menurun) }\end{array}$ \\
\hline $2007(1)$ & $4,389,693,015$ & $9,002,842,989$ \\
\hline $2008(2)$ & $4,985,023,234$ & $7,195,438,865$ \\
\hline $2009(3)$ & $5,446,588,824$ & $6,213,429,490$ \\
\hline $2010(4)$ & $5,808,386,447$ & $5,396,474,067$ \\
\hline $2011(5)$ & $5,763,678,928$ & $5,848,131,183$ \\
\hline $2012(6)$ & $6,444,501,890$ & $7,975,615,125$ \\
\hline
\end{tabular}

Menurut Catatan Atas Laporan Keuangan Yang Berakhir Tanggal 31 Desember 2012 dan 2011 PT.ABC-RS.XYZ Dalam Laporan 
Auditor Independen Atas Laporan Keuangan Untuk Tahun Yang Berakhir Tanggal 31 Desember 2012 dan 2011, menyatakan bahwa Penyusutan dihitung dengan menggunakan Metode Garis Lurus berdasarkan taksiran masa manfaat ekonomi aset tetap yang bersangkutan.

Dibandingkan penggunaan metode Saldo Menurun atauDouble Declining Balance (DDB), metode penyusutan garis lurus akan menghasilkan beban depresiasi yang relatif lebih kecil, sehingga laba yang dihasilkan menjadi lebih tinggi,

tetapi pada tahun ke-4 beban depresiasi metode DDB menjadi relatif lebih kecil dibandingkan dengan beban depresiasi metode garis lurus, sehingga dengan penggunaan metode penyusutan DDB akan menyebabkan penyajian laba pada tahun ke-4 menjadi lebih besar. Walaupun demikian perusahaan tetap konsisten menggunakan penyusutan metode garis lurus.

2. Penentuan Umur Ekonomis Pada Aset Tetap Dan Tidak Berwujud

Menurut PSAK 16 (Revisi 2011) dalam Catatan Atas Laporan Keuangan Yang Berakhir Tanggal 31 Desember 2012 dan 2011 PT.ABC-RS.XYZ-Laporan Auditor Independen Atas Laporan Keuangan Untuk Tahun Yang Berakhir Tanggal 31 Desember 2012 dan 2011, menyatakan bahwa ;

Aset tetap dinyatakan sebesar biaya perolehan dikurangi akumulasi penyusutan.

Penyusutan dihitung dengan menggunakan Metode Garis Lurus berdasarkan taksiran masa manfaat ekonomi aset tetap yang bersangkutan sebagai berikut ; 
1. Inventaris IT umur ekonomis 4 tahun.

2. Peralatan Medis umur ekonomis 10 tahun.

3. Peralatan Kamar Pasien umur ekonomis 8 tahun.

4. Peralatan Lain umur ekonomis 4 tahun.

5. Kendaraan umur ekonomis 5 tahun.

6. Peralatan Masak umur ekonomis 5 tahun.

7. Perlengkapan masak umur ekonomis 5 -tahun.

8. Beban Pra Operasi umur ekonomiske athun.

Umur ekonomis aset tetap maupun aset tidak berwujud yang ditetapkan perusahaan secara konsisten diterapkan oleh perusahaan, tidak ada perubahan-perubahan umur ekonomis pada penambahan aset-aset pada tahun-tahun berikutnya.

Tabel 2 : Perbandingan Antara Umur Ekonomis Aset Tetap dan Aset Tidak Berwujud Menurut Kebijakan Perusahaan dan Menurut Undang-Undang Pajak

No 17 Tahur 2000

\begin{tabular}{|l|c|c|}
\hline \multicolumn{1}{|c|}{ Tahun } & $\begin{array}{c}\text { Umur ekonomis } \\
\text { menurut kebijakan } \\
\text { perusahaan }\end{array}$ & $\begin{array}{c}\text { Umur ekonomis menurut uu } \\
\text { perpajakan no 17 tahun 2000. }\end{array}$ \\
\hline Inventaris IT & 4 tahun & 4 tahun \\
\hline Peralatan Medis & 10 tahun & 4 tahun \\
\hline Peralatan KamarPasien & 8 tahun & 4 tahun \\
\hline Peralatan Lain & 4 tahun & 4 tahun \\
\hline Kendaraan & 5 tahun & 8 tahun \\
\hline Peralatan Masak & 5 tahun & 4 tahun \\
\hline Perlengkapan Masak & 5 tahun & 4 tahun \\
\hline Beban Pra Operasi & 10 tahun & 8 tahun \\
\hline
\end{tabular}

Tabel 3. Perbandingan Beban Depresiasi Berdasarkan Umur Ekonomis Kebijakan Perusahaan dan Umur Ekonomis Menurut UU Perpajakan No 17 Tahun 2000 


\begin{tabular}{|c|c|c|}
\hline Tahun & $\begin{array}{c}\text { Beban depresiasi berdasar } \\
\text { umur eknomis perusahaan }\end{array}$ & $\begin{array}{c}\text { Beban depresiasi berdasar } \\
\text { umur ekonomis Uu no. 17 } \\
\text { tahun 2000. }\end{array}$ \\
\hline 2007 & $8,082,557,347$ & $4,389,693,015$ \\
\hline 2008 & $8,531,020,772$ & $4,985,023,234$ \\
\hline 2009 & $9,506,525,495$ & $5,446,588,824$ \\
\hline 2010 & $10,037,427,266$ & $5,808,386,447$ \\
\hline 2011 & $11,725,415,511$ & $5,763,678,928$ \\
\hline 2012 & $9,527,381,861$ & $6,444,501,890$ \\
\hline
\end{tabular}

Dibandingkan dengan penggunaan umur ekonomis pada metode penyusutan aktiva tetap menurut UU Pajak no 17 tahun 2000, penggunaan umur ekonomis yang ditetapkan perusahaan pada aset tetap maupun aset tidak berwujud akan menghasilkan beban depresiasi yang relatif lebih rendah, sehingga akan menyebabkan laba yang lebih rendah dalam penyajian laba.

5. Estimasi Penentuan Piutang Tidak Tertagih

Kebijakan Departemen Keuangan Perusahaan menetapkan prosentase Piutang Tidak Tertagih setiap tahunnya adalah sebesar $1 \%$ dari total piutang.

Tabel 4: Perbandingan Penetapan Piutang Tidak Tertagih Antara Persentase Piutang dan Persentase Pendapatan

\begin{tabular}{|c|c|c|}
\hline Tahun & Persentase piutang & Persentase pendapatan \\
\hline 2007 & 741,189 & $96,594,363$ \\
\hline 2008 & $14,327,351$ & $332,171,140$ \\
\hline 2009 & $29,131,851$ & $469,568,802$ \\
\hline 2010 & $47,956,752$ & $562,746,554$ \\
\hline 2011 & $50,483,764$ & $621,308,631$ \\
\hline 2012 & $63,508,694$ & $833,796,358$ \\
\hline
\end{tabular}


Jika dibandingkan dengan estimasi piutang dengan persentase dari pendapatan maka jumlah estimasi piutang tidak tertagih kebijakan perusahaan yang relatif lebih kecil, kebijakan ini berimplikasi pada prestasi manajemen.

\section{Kesimpulan dan Saran}

\section{Kesimpulan}

Dari hasil penelitian dan pembahasan diperoleh kesimpulan sebagai berikut :

1. Creative accounting yang dilakukan perusahaan adalah pada pemilihan perhitungan depresiasi Metode Garis Lurus secara konsisten. Teknik ini legal yang diperbolehkan SAK, Perusahaan tidak memiliki potensi permasalahan akuntansi (potensial red flag), karena penggunaan metode ini konsisten dari tahun ke tahun.

2. Creative accounting yang dilakukan dalam penetapan umur ekonomis pada aset tetap dan aset tidak berwujud adalah ditetapkan dari mulai 4 tahun sampai dengan 10 tahun, penetapan ini adalah kebijakan perusahaan yang dijalankan konsisten dari tahun ke tahun. Teknik ini legal yang diperbolehkan SAK, perusahaan tidak memiliki potensi permasalahan akuntansi (potensial red flag).

3. Creative accountingyang dilakukan pada estimasi persentase piutang tidak tertagih adalah sebesar $1 \%$ dari piutang tiap tahunnya, dibandingkan dengan persentase dari pendapatan, persentase dari piutang akan menghasilkan piutang tidak tertagih yang lebih relatif lebih kecil, tapi kebijakan perusahaan dilakukan 
secara konsisten setiap tahunnya, perusahaan tidak memiliki potensi permasalahan akuntansi (potensial red flag).

4. Creative accountingyang dijalankan perusahaan berbentuk teknik legal yang diperbolehkan dalam SAK, kebijakan akuntansi dan keuangan yang bertujuan penyajian laba lebih tinggi tidak mengalami perubahan-perubahan/konsisten dalam kondisi apapun, konsekuensi penyajian laba yang lebih tinggi yaitu pajak penghasilan badan yang muncul akibat pemilihan metode dan estimasi akuntansi juga tetap dipenuhi perusahaan.

\section{Saran}

Bagi peneliti yang akan datang, disarankan untuk memperluas fokus penelitian dan pada perusahaan yang berbeda, sehingga dengan fokus penelitian yang lebih luas akan menghasilkan hasil dan temuan yang lebih baik. 


\section{DAFTAR PUSTAKA}

Sulistiawan, Dedhy. Januarsi, Yeni dan Alvia, Liza. 2011. Creative Accounting Mengungkap Manajemen Laba dan Skandal Akuntansi. Jakarta : Penerbit Salemba Empat.

Griffin, Ricky W. Ebert, Ronald J. 2007. Bisnis Edisi Kedelapan Jilid 1. Jakarta : Penerbit Erlangga.

Griffin, Ricky W. Ebert, Ronald J. 2007. Bisnis Edisi Kedelapan Jilid 2. Jakarta : Penerbit Erlangga.

Samiaji, Iji, SE, M.Si, Ak, CA, BKP. 2013. Ulasan Teknis Manakah Yang Bisa Menyebabkan Skandal Akuntansi. Jakarta Pusat: Majalah Akuntan Indonesia.

Jusup, Al Haryono, Drs, MBA, Akuntan. 1998. Dasar-Dasar Akuntansi Jilid 2 Edisi 5. Yogyakarta : Sekolah Tinggi Ilmu Ekonomi YKPN.

Hadori, Sugiarto, Adi dan Rekan, KAP. 2012. Laporan Auditor Independen Atas Laporan Keuangan Untuk Tahun Yang Berakhir Tanggal 31 Desember 2012 dan 2011. Yogyakarta : Hadori, Sugiarto dan Rekan.

Hadori, Sugiarto, Adi dan Rekan, KAP. 2011. Laporan Auditor Independen Atas Laporan Keuangan Untuk Tahun Yang Berakhir Tanggal 31 Desember 2011 dan 2010. Yogyakarta : Hadori, Sugiarto dan Rekan.

Hadori, Sugiarto, Adi dan Rekan, KAP. 2010. Laporan Auditor Independen Atas Laporan Keuangan Untuk Tahun Yang Berakhir Tanggal 31 Desember 2010 dan 2009. Yogyakarta : Hadori, Sugiarto dan Rekan.

Hadori, Sugiarto, Adi dan Rekan, KAP. 2009. Laporan Auditor Independen Atas Laporan Keuangan Untuk Tahun Yang Berakhir Tanggal 31 Desember 2009 dan 2008. Yogyakarta : Hadori, Sugiarto dan Rekan.

Hadori, Sugiarto, Adi dan Rekan, KAP. 2008. Laporan Auditor Independen Atas Laporan Keuangan Untuk Tahun Yang Berakhir Tanggal 31 Desember 2008 dan 2007. Yogyakarta : Hadori, Sugiarto dan Rekan.

Hadori, Sugiarto, Adi dan Rekan, KAP. 2007. Laporan Auditor Independen Atas Laporan Keuangan Untuk Tahun Yang Berakhir Tanggal 31 Desember 2007. Yogyakarta : Hadori, Sugiarto dan Rekan.

Maryana, Meida.2010. Pengaruh Budaya Organisasi terhadap Sistem Informasi Akuntansi dan 'Implikasinya pada Pengendalian $2079 \cdots$ 
$\because$ Internal (Survey pada 10 KPP Bandung Kanwil Jawa Barat I). Jakarta : Universitas Komputer Indonesia.

Triyuwono, I.2000. Organisasi dan Akuntansi Syariah. Yogyakarta : LKIS.

Widarto. Sudarma, Made. Baridwan, Zaki. Analisa Kritis Terhadap Praktek Akuntansi Syariah. Malang : Universitas Brawijaya.

Widuri, Rindang. Paramita, Asteria. 2007. Analisis Hubungan Peranan Budaya Perusahaan Terhadap Penerapan Good Corporate Governance Pada PT. Aneka Tambang. Journal The Winners.

Departemen Keuangan. 2000. Undang-Undang Pajak No.17 Tahun 2000 Metode Penyusutan Aktiva Tetap. Jakarta : Departemen Keuangan.

Menteri Keuangan. 2009. Peraturan Menteri Keuangan Republik Indonesia Nomor 96/PMK.03/2009 Jenis-Jenis Harta Yang Termasuk Dalam Kelompok Harta Berwujud Bukan Bangunan Untuk Keperluan Penyusutan. Jakarta : Departemen Keuangan. 